\title{
Product Characteristics from the Torrefaction of Bamboo Pellets in Oxidative Atmosphere
}

\author{
Jacky Michael Pah ${ }^{1}$ Lisman Suryanegara ${ }^{2}$ Agus Haryanto $^{1}$ Udin Hasanudin ${ }^{1}$

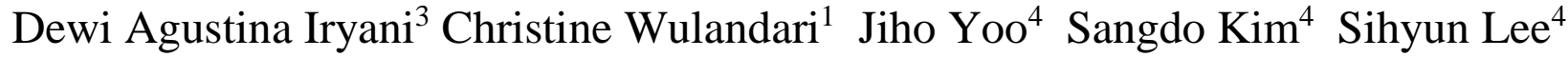 \\ Wahyu Hidayat ${ }^{1, *}$
}

\author{
${ }^{1}$ Faculty of Agriculture, University of Lampung, Jl. Sumantri Brojonegoro 1, Bandar Lampung, 35145, Indonesia \\ ${ }^{2}$ Research Center for Biomaterials, Indonesian Institute of Sciences, Cibinong 16911, West Java, Indonesia \\ ${ }^{3}$ Faculty of Engineering, University of Lampung, Jl. Sumantri Brojonegoro 1, Bandar Lampung, 35145, Indonesia \\ ${ }^{4}$ Climate Change Research Division, Korean Institute of Energy Research, Daejon, 34129, Republic of Korea \\ *Corresponding author. Email: wahyu.hidayat@fp.unila.ac.id
}

\begin{abstract}
Bamboo is a potential energy crop for the future and an attractive option to replace wood due to its fast growth, high productivity, and essential fuel characteristics such as low ash content, alkali index, and high heating value. This study aimed to evaluate the effects of torrefaction on the physical properties of andong (Gigantochloa pseudoarundinacea) and betung (Dendrocalamus asper) bamboo pellets. Torrefaction of bamboo pellets was conducted in an oxidative atmosphere using an electric furnace at $280^{\circ} \mathrm{C}$ with a residence time of $40 \mathrm{~min}$. The results showed that oxidative torrefaction caused a decrease in the equilibrium moisture content of bamboo pellets. Water resistance and water adsorption test showed that the torrefied pellets are more resistant to water and relative humidity than the non-torrefied pellet, which is beneficial when the pellet is stored for a long time and in humid conditions. The results also showed that the density of bamboo pellets decreased after torrefaction.
\end{abstract}

Keywords: Bamboo pellet, Dendrocalamus asper, Gigantochloa pseudoarundinacea, oxidative torrefaction

\section{INTRODUCTION}

Biomass energy is a very potential alternative energy source in Indonesia. Biomass is organic material derived from plants [1]. Indonesia has abundant biomass resources, both in the form of raw materials and waste [2]. Bamboo is one of the biomass which has potential as an alternative energy source [3]. Biomass has disadvantages when used as a solid fuel because it has variations in size and shape that cause difficulties in handling and storage, making it uneconomical to transport over long distances [4].

Biomass needs to be processed through densification so that its use is more practical. Densification is a technique of converting biomass into fuel with the aim of increasing density and facilitating storage and transportation because it has uniform size and quality. One of the biomass densification products is biomass pellets. Pellets are biomass that is reduced in size, then compacted so that it has a cylindrical shape that can be used as fuel [5]. Density affects the quality of solid fuel because high density can increase the energy density of the fuel. Research shows that size reduction can reduce transportation costs and facilitate storage and handling [6]. Biomass pellets are one of the products developed as an alternative to new energy sources used as fuel. Pellets can be used as fuel for household, agricultural, and large industrial needs, and even for the power generation industries.

Pellets as a biomass energy source have advantages compared to other biomass energy sources, such as briquettes and chips, especially in density and uniformity of shape [7]. This higher density results in lower transportation costs and efficiency in terms of greater energy conversion [8], while a reduction in moisture content increases storage duration. Indonesia has a bamboo forest area of around 2,000,000 ha, the third largest in Asia [9]. Andong (Gigantochloa 
pseudoarundinacea (Steudel) Widjaja) and betung (Dendrocalamus asper) is a type of bamboo that grows in Indonesia which is used for household appliances, crafts, and building materials. Bamboo is a lignocellulosic material consisting of cellulose, hemicellulose, and lignin; hence it can be used as a substitute for wood for several purposes [10]. The growth rate of bamboo is faster than wood, so it has a short cutting cycle and can be planted easily in almost any type of soil [11]. Bamboo biomass a potential to be developed as a source of raw material for pellet production in Indonesia.

Many studies on torrefaction of biomass pellets have been conducted [5,12,13]. However, study on the torrefaction of bamboo pellet is still lacking [14]. Therefore, the aim of this study was to evaluate the effects of torrefaction on the energy properties of andong and betung bamboo pellets.

\section{MATERIALS AND METHOD}

\subsection{Material Preparation and Bamboo Pellet Production}

Andong (Gigantochloa pseudoarundinacea (Steudel) Widjaja) and betung (Dendrocalamus asper) aged two years were collected from Ciawi, Bogor Regency, West Java, Indonesia (coordinates 6 40'49,3" South Latitude and 106 $49^{\prime} 49,6^{\prime \prime}$ East Longitude). Preparation of bamboo particles and production of bamboo pellets was conducted at the Research Center for Biomaterials, Indonesian Institute of Sciences, Cibinong, West Java, Indonesia. Andong and betung bamboos were used to produce the pellets.

A total of 50 stalks for each bamboo were felled on the fourth node from the ground with an average length of $9 \mathrm{~m}$. The bamboo culms were then dried outdoors for one week, then cut using a circular saw into three parts, namely the bottom, middle, and top, with a length of $3 \mathrm{~m}$ each. Each piece was then split into small strips, and the outer and inner shells were removed using a planer machine. The bamboo strip without the skin was cut into small pieces and then put into a grinding machine to produce bamboo particles or powder. The powder was then dried until it reaches a moisture content of $\pm 12 \%$, then fed into a pellet machine with a processing capacity of 1 ton/h (Model HM560A, Shandong HM Better Pellet Mill Machinery, China) and was compressed into pellets. The bamboo pellets were cooled down and then put into plastic containers.

\subsection{Torrefaction of Bamboo Pellets}

Bamboo pellets that have been prepared were weighed and then wrapped using aluminum foil. The bottom part of the wrap was then perforated using a needle. Torrefaction of bamboo pellets was conducted using an electric furnace at $280{ }^{\circ} \mathrm{C}$ with a residence time of $40 \mathrm{~min}$. After 40 minutes, the samples were removed from the furnace and then put in room condition at a temperature of $25-30^{\circ} \mathrm{C}$ with relative humidity $(\mathrm{RH})$ of $70-80 \%$.

\subsection{Evaluation of Bamboo Pellets}

The density, moisture content, and water resistance of bamboo pellets before and after torrefaction were evaluated. The density test was carried out using the oven-dry samples based on the KS F 2198 standard [15]. The sample was weighed, and then the average length and diameter were measured to determine the volume of the pellet sample. The measurement of moisture content was conducted following KS F 2199 standard [16]. Air dry weight and oven-dry weight were measured to determine the moisture content of the samples before and after torrefaction. The density $(\rho)$ and moisture content (MC) were calculated as the following:

$$
\begin{aligned}
& \rho=m_{\mathrm{od}} / V_{\mathrm{od}} \\
& M C=\frac{m-m_{o d}}{m} \times 100 \%
\end{aligned}
$$

where $m_{\text {od }}$ is the oven-dry weight of the sample $(\mathrm{g}), m$ is the initial weight of the sample $(\mathrm{g})$, and $V_{\text {od }}$ is the ovendry volume of the sample $(\mathrm{g})$.

The water-resistance test was conducted by immersing bamboo pellets in water and observing the visual changes in bamboo pellets after soaking for 5, 30 minutes, and 1 hour. The water adsorption of the pellet was measured by placing the pellet in a room with ambient temperature and observing the mass changes for one month.

\section{RESULTS AND DISCUSSION}

\subsection{Density}

The density of bamboo pellets before and after torrefaction is shown in Figure 1. The results showed that torrefaction with an electric furnace $(\mathrm{EF})$ resulted in a decrease in bamboo pellet density. Bamboo pellets without torrefaction have a density of $1.26 \mathrm{~g} / \mathrm{cm}^{3}$ and $1.30 \mathrm{~g} / \mathrm{cm}^{3}$ respectively, for andong and betung. The bamboo pellet density decreased to $1.2 \mathrm{~g} / \mathrm{cm}^{3}$ after being torrefied with $\mathrm{EF}$ at temperature $280{ }^{\circ} \mathrm{C}$ for 40 minutes. The decrease in density occurred because of the removal of water and extractive components that make the mass of bamboo pellets decreased after torrefaction [17].

\subsection{Moisture Content}

The moisture content (MC) of bamboo pellets before and after torrefaction is shown in Figure 2. The results showed that the MC decreased after torrefaction using EF. Andong and betung bamboo pellets before torrefaction had an MC of 6,58\% and 4,03\% and. The MC of bamboo pellets decreased after torrefaction $280^{\circ} \mathrm{C}$, reaching $2.02 \%$ for andong and $1.89 \%$ for betung. The results are 
in line with previous study [13], showing the rubberwood pellets before torrefaction with an $\mathrm{MC}$ of $12.25 \%$ decreased after torrefaction up to $3.54 \%$ [13]. Torrefaction at relatively high temperature causes evaporation of water and extractive materials as well as degradation of hemicellulose so that $\mathrm{MC}$ is decreasing [18].

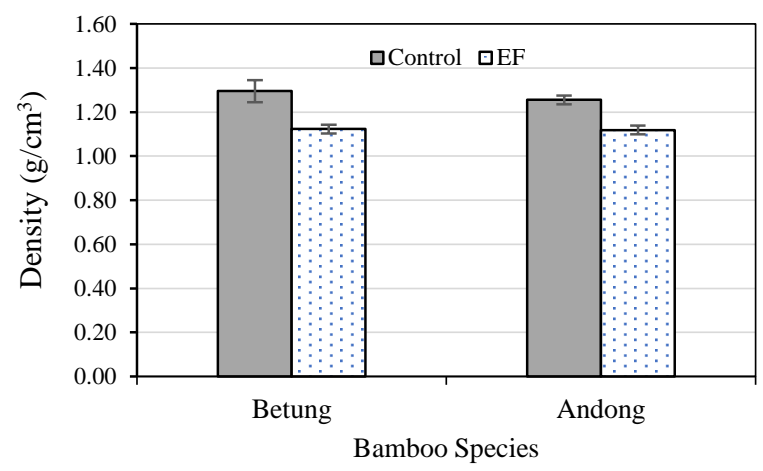

Figure 1. Density of bamboo pellets before and after torrefaction

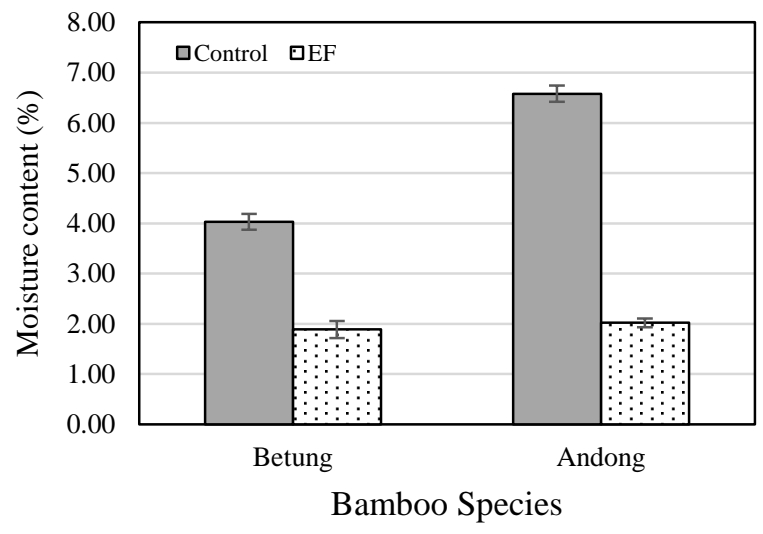

Figure 2. Moisture content of bamboo pellets before and after torrefaction

\subsection{Water Resistance}

Water-resistance testing was carried out to determine the resistance of the pellets to the rate of absorbing water for a time limit of up to 1 hour. Figure 3 reveal correspondingly the andong and betung bamboo pellets before and after torefaction that have not been given water resistance test treatment.

The water resistance of bamboo pellets before and after torrefaction is shown in Figure 4 and Figure 5. The control samples of andong and betung bamboo pellets began to show physical changes in the form of pellet development after soaking for 5 minute. The pellets are expanding after soaking for 30 minutes and 1 hour. Research using rubber and jabon wood pellets show that the pellets began to disintegrate after immersing in water for 5 minutes and got worse after immersion for 24 hours $[12,13]$.
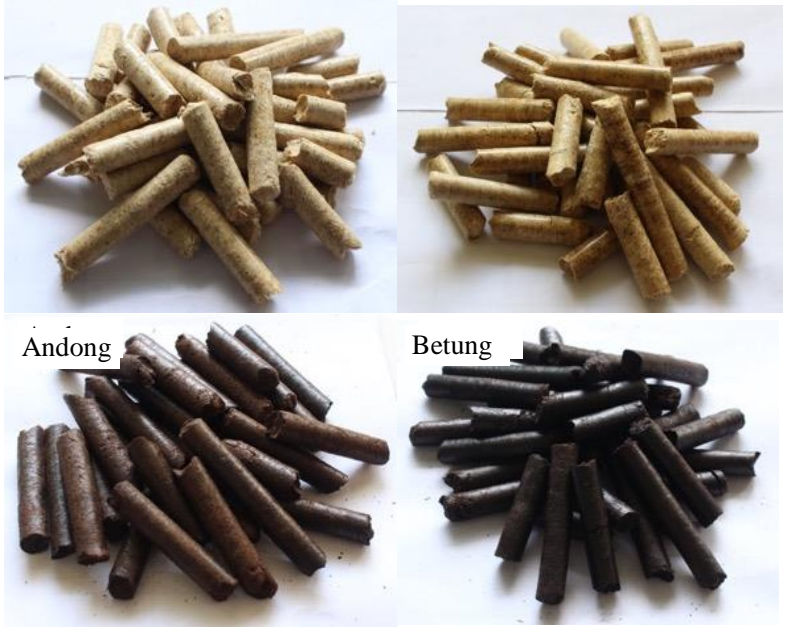

Figure 3. Visual appearance of andong and betung bamboo pellets: before (top) and after torefaction (bottom)

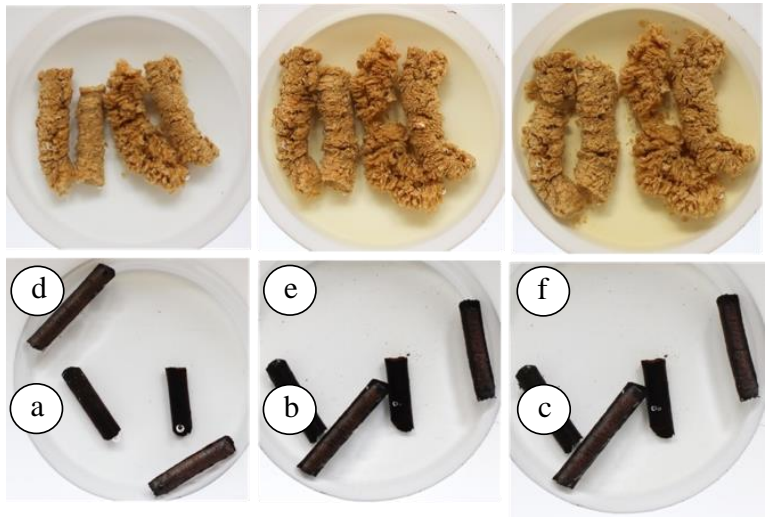

Figure 4. Changes in the andong bamboo pellets after soaking in water for: (a, d) 5 minutes, (b, e) 30 minutes, and (c, f) 1 hour

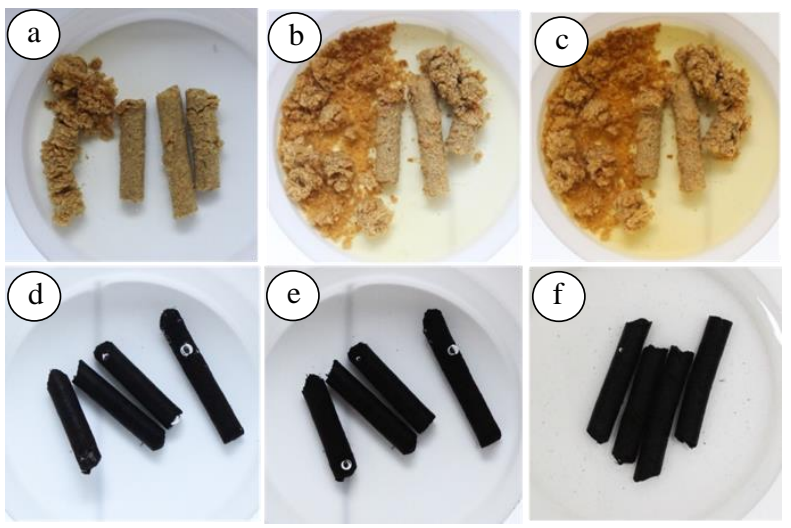

Figure 5. Changes in the betung bamboo pellets after soaking in water for: (a, d) 5 minutes, $(b, e) 30$ minutes, and (c, f) 1 hour

The torrefaction of pellets from andong and betung bamboo using EF at $280{ }^{\circ} \mathrm{C}$ did not show any damage even after soaking for 1 hour. Based on the test results of moisture content and water absorption, torrefaction 
changes the hygroscopic properties of bamboo pellets from hydrophilic (tend to absorb water) to hydrophobic (resistant to water). The hydrophobic properties of pellets are very advantageous in storage as well the application.

\subsection{Water Adsorption}

The water adsorption observations of bamboo pellets before and after torrefaction were carried out for 30 days and the results are presented in Figure 6.

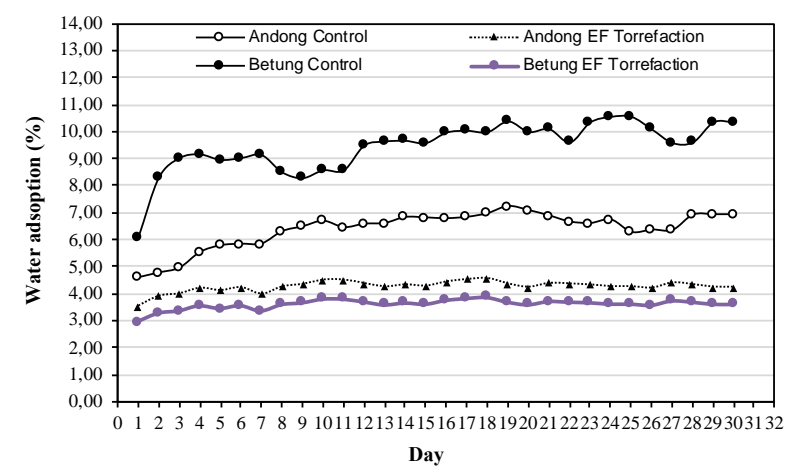

Figure 6. Water adsorption of bamboo pellets before and after torrefaction

Control bamboo pellets, especially in betung bamboo pellets, the percentage of water adsorption is very volatile because it is easily affected by changes in relative humidity. In contrast, in bamboo pellets after torrefaction, the percentage of water adsorption was not as volatile as the control pellets. The presence of water in the biomass pellets has an essential role in hydrophobic behavior [15]. As an indicator of hydrophobicity, MC of biomass pellets before and after torrefaction is specified, and the results presented in Figure 2 indicate that bamboo pellet after torrefaction is highly hydrophobic.

\section{CONCLUSION}

The results showed that oxidative torrefaction caused a decrease in the equilibrium moisture content of bamboo pellets. Water resistance and water adsorption test showed that the torrefied pellets were more resistant to water and relative humidity than the non-torrefied pellet, which is beneficial when the pellet was stored for a long time and in humid conditions. The results also showed that the density of bamboo pellets decreased after the torrefaction process.

\section{AUTHORS' CONTRIBUTIONS}

JMP: Conception and experiment design, data collection, analysis and interpretation, writing the article draft.

LS: Provision of materials and pellets production.

AH, UH, DAI, CW: Conception and experiment design, critical review and revision of the draft.

JY, SK, SL: Obtaining funding.
WH: Conception and experiment design, critical review and revision of the draft, final approval of the article.

\section{REFERENCES}

[1] A. Demirbas, Biofuels from Agricultural Biomass, Energy Sources Part A, 31:1573-1582, 2009.

[2] A. Arhamsyah, Pemanfaatan biomassa kayu sebagai sumber energi terbarukan, Jurnal Riset Industri Hasil Hutan, 2(1): 42-48, 2010.

[3] A. Aisman, Kajian dasar potensi energi listrik berbasis biomasa bambu di Kabupaten Kepulauan Mentawai. Jurnal Agroindustri, 6(2): 65-72, 2016.

[4] R. Alamsyah, C.N. Siregar, F. Hasanah, Torrefaction study for energy upgrading on Indonesian biomass as low emission solid fuel, in: International Conference on Biomass: Technology, Application, and Sustainable Development, 2017.

[5] M. Syamsiro, Peningkatan Kualitas Bahan Bakar Padat Biomassa Dengan Proses Densifikasi Dan Torrefaksi. Jurnal Mekanika dan Sistem Termal, 1(1): 7-13, 2016.

[6] Lehtikangas, P. 2001. Quality Properties of Pelletised Sawdust, Logging Residues and Bark. Biomass and Bioenergy 20 (2001) 351-360.

[7] P. Lehtikangas, Quality Properties of Pelletised Sawdust, Logging Residues and Bark. Biomass and Bioenergy, 20: 351-360, 2001.

[7] J.I. Arranz, M.T. Miranda, I. Montero, F.J. Sepúlveda, C.V. Rojas, Characterization and combustion behaviour of comercial and experimental wood pellets in South West Europe, Fuel, 142: 199-207, 2015. DOI: 10.1016/j.fuel. 2014.10.059

[8] M.T. Carone, A. Pantaleo, A. Pellerano, Influence of process parameters and biomass characteristics on the durability of pellets from the pruning residues of Olea europaea L, Biomass and Bioenergy, 35(1): 402-410, 2011

[9] FAO, Global Forest Resources Assessment Update 2005: Indonesia Country Report on Bamboo Resources, Food and Agreculture Organization and International Network for Bamboo and Rattan (INBAR), Jakarta, May, 2005.

[10] S.R. Sutardi, N. Nadjib, M. Muslich, Jasni, I.M. Sulastiningsih, S. Komaryati, S. Suprapti, Abdurrahman, E. Basri, Informasi Sifat Dasar dan Kemungkinan Penggunaan 10 Jenis Bambu. Pusat Penelitian dan Pengembangan Hasil Hutan Badan Penelitian, Pengembangan dan Inovasi Kementerian Lingkungan Hidup dan Kehutanan, Bogor, 2015. 
[11] M.I. Maulana, D.S. Nawawi, N.J. Wistara, R.K. Sari, S. Nikmatin, S. Maulana, S-H. Park, F. Febrianto, 2018. Perubahan Kadar Komponen Kimia Bambu Andong akibat Perlakuan Steam. Jurnal Ilmu Teknol. Kayu Tropis, 16(1): 83-92, 2018.

[12] Y. Sulistio, I.G. Febryano, J. Yoo, S. Kim, S. Lee, U. Hasanudin, W. Hidayat, Pengaruh Torefaksi dengan Reaktor Counter-Flow Multi Baffle (COMB) dan Electric Furnace terhadap Pelet Kayu Jabon (Anthocephalus cadamba). Jurnal Sylva Lestari 8(1): 65-76, 2020. DOI: 10.23960/js1186576

[13] T. Rubiyanti, W. Hidayat, I.G. Febryano, S. Bakri, Karakterisasi Pelet Kayu Karet (Hevea brasiliensis) Hasil Torefaksi dengan Menggunakan Reaktor Counter-Flow Multi Baffle (COMB). Jurnal Sylva Lestari 7(3): 321-331, 2019. DOI: 10.23960/ js137321-331

[14] Z.J. Liu, B.H. Fei, Z.H. Jiang, Z.Y. Cai, X.E. Liu, Important properties of bamboo pellets to be used as commercial solid fuel in China. Wood Sci Technol, 48: 903-917, 2014.
[15] KSA. 2011a. KS F 2198: Determination of Density and Specific Gravity of Wood. Korean Standards Association, Seoul, Republic of Korea.

[16] KSA. 2011b. KS F 2199: Determination of Moisture Content of Wood. Korean Standards Association, Seoul, Republic of Korea.

[17] Z.J. Liu, X. Liu, B. Fei, Z. Jiang, Z. Cai, Y. Yu, The properties of pellets from mixing bamboo and rice straw. Renewable Energy 55(1): 1-5, 2013. DOI: 10.1016/j.renene.2012.12.014

[18] W. Hidayat, J.H. Jang, S.H. Park, Y. Qi, F. Febrianto, S.H. Lee, N.H. Kim, Effect of Temperature and Clamping during Heat Treatment on Physical and Mechanical Properties of Okan (Cylicodiscus gabunensis [Taub.] Harms) Wood. BioResources 10(4): 6961-6974, 2015. DOI: 10.15376/biores.10.4.6961-6974

[19] Y. Zhang, F. Chen, D. Chen, K. Cen, J. Zhang, X. Cao, Upgrading of Biomass Pellets by Torrefaction and Its Influence on The Hydrophobicity, Mechanical Property, and Fuel Quality. Biomass Conversion and Biorefinery, 2020. DOI: 10.1007/s13399-020-00666-5. 